\title{
PEMBUATAN BUSANA FANTASI DENGAN SUMBER IDE DRAMATARI CALONARANG
}

\author{
I Luh Ade Haryawati ${ }^{1)}$, I Gede Sudirtha ${ }^{1)}$, Made Diah Angendari ${ }^{2)}$ \\ Program Studi Pendidikan Kesejahteraan Keluarga, Fakultas Teknik dan Kejuruan \\ Universitas Pendidikan Ganesha \\ Singaraja, Indonesia \\ e-mail :Adeharywati25@gmail.com gede.sudirtha@undiksha.ac.id 2. \\ diah.angendari@undiksha.ac.id
}

\begin{abstract}
Abstrak
Penelitian ini bertujuan untuk (1) mendeskripsikan proses pembuatan busana fantasi dengan sumber ide Dramatari Calonarang; (2) mendeskripsikan hasil dari pembuatan busana fantasi dengan sumber ide Dramatari Calonarang. Penelitian ini merupakan penelitian pengembangan (Research and Development), menggunakan model pengembangan PPE. Proses penelitian pengembangan busana ini dilakukan melalui beberapa tahap, yaitu yang terdiri dari 3 tahap yaitu: Perencanaan (planning), produksi (production), evaluasi (evaluation). (1) Pengumpulan data yang digunakan dalam pengembangan ini adalah angket. Proses dari pembuatan buasana fantasi melalui beberapa tahap yakni tahap perencanaan hal pertama yang dilakukan adalah menganalisis terhadap sumber ide yang dikembangkan menjadi busana. Kemudian dilanjutkan dengan proses perancangan atau desain. Pada proses ini peneliti membuat desain busana berdasarkan analisis. Setelah proses perencanaan, kemudian tahap selanjutnya yaitu produksi. Pada proses pengembangan terdiri dari dua langkah yaitu, persiapan dan pelaksanaan. Tahap evaluasi dilakukan uji produk terhadap hasil dari pengembangan busana. (2) Hasil pembuatan busana fantasi dengan sumber ide Dramatari Calonarang terdiri dari dua busana dengan siluet A dan I yang bersumber ide dari tokoh busana penari Matah Gede. Berdasarkan hasil uji produk busana fantasi dari ahli busana I dan ahli II mendapatkan hasil 98,5\%. Hal menunjukan bahwa pembuatan busana fantasi dengan sumber ide Dramatari Calonarang memiliki tingkat pencapaian sangat baik.
\end{abstract}

Kata Kunci: Busana Fantasi, Dramatari Calonarang, Sumber Ide.

\section{Abstract}

This study aims to (1) describe the process of making fantasy fashion with the source of Dramatari Calonarang's ideas; (2) describe the results of making a fantasy outfit with the source of Dramatari Calonarang's ideas. This research is a research and development, using PPE development model. The clothing development research process is carried out through several stages, consisting of 3 stages: planning, production, evaluation. (1) Data collection used in this development is a questionnaire. The process of making fantasy atmosphere through several stages namely the planning stage the first thing to do is to analyze the source of ideas developed into clothing. Then proceed with the design process. In this process the researcher makes a fashion design based on analysis. After the planning process, then the next stage is production. In the development process consists of two steps, namely, preparation and implementation. The product evaluation phase is tested on the results of clothing development. (2) The results of making a fantasy outfit with the source of ideas Dramatari Calonarang consists of two outfits with silhouettes A and I sourced from the fashion figure of the dancer Matah Gede. Based on the test results of fantasy fashion products from fashion experts I and experts II get $98.5 \%$ results. This shows that the making of fantasy fashion with the source of ideas from Dramatari Calonarang has a very good level of achievement.

Keywords: Fantasy Clothing, Development, Idea Source. 


\section{PENDAHULUAN}

Busana merupakan kebutuhan yang sangat penting dalam kehidupan manusia. Hal ini juga menjadikan busana sebagai salah satu kebutuhan pokok yang harus dipenuhi. Busana dipakai sebagai pelindung tubuh dari sengatan matahari dan rasa dingin. Tidak hanya kedua fungsi tersebut yang menjadi tujuan utama berbusana, tetapi busana menjadi bagian penting dari hidup manusia karena mengandung unsur etika dan estetika dalam masyarakat. Busana yang harmonis dan serasi akan menambah baik penampilan diri kita.

Menurut Arifah, Riyanto (2003:2) busana merupakan bahan tekstil atau bahan lainnya yang sudah dijahit maupun tidak dijahit yang dipakai selain itu dapat disampirkan untuk penutup tubuh seseorang. Busana sendiri mencakup dari busana pokok, pelengkap (millineris dan aksesori), serta tata riasnya. Sementara itu, secara makro busana meliputi, yaitu busana mutlak millineris, dan aksesoris. Busana mutlak merupakan busana yang tergolong busana pokok, seperti baju, rok, kebaya, blus dan lain- lain, serta pakaian dalam, misalnya singlet, dan celana dalam (al-Firdaus, 2010:11).

Perkembangan teknologi dapat mempengaruhi kehidupan dan kebudayaan, demikian pula dalam hal berbusana, yaitu melalui media komunikasi, film, televisi, majalah, dan peragaan busana. Suksesnya dunia fashion menjadi inspirasi untukmenciptakan busana yang memiliki nilai seni. Banyak sumber ide di sekeliling kita yang mampu menunjang kreatifitas pecinta dunia fashion dalam menciptakan serta menghasilkan sesuatu yang baru dan menarik. Semakin berkembangnya teknologi yang ada, maka semakin berkembang juga trend fashion yang ada. Kini trend fashion pun hadir dengan berbagai keunikan dan tampilan yang lebih beragam, salah satunya busana fantasi. Fantasi merupakan khayalan, impian, sesuatu yang tidak nyata (Kamus Besar Bahasa Indonesia, 2019:96). Busana fantasi dapat dikenakan pada peristiwa-peristiwa khusus, misalnya acara adat, pawai/karnaval, perayaan hari besar keagamaan serta sebagai kostum pada saat pementasan di atas panggung.

Macam-macam bentuk busana fantasi dapat diciptakan melalui sebuah sumber ide. Dimana sumber ide inilah yang akan membawa busana fantasi menjadi terlihat menarik dan unik karena akan mempengaruhi siluet, cutting, serta teknik pembuatan busana. Dalam menciptakan busana fantasi dengan sebuah sumber ide, perlu diperhatikan beberapa aspek untuk menerapkan sumber ide tersebut agar dapat tersusun dengan rapi pada busana. Aspek-aspek tersebut adalah unsur dan prinsip desain busana. Penerapan unsur dan prinsip desain akan memudahkan suatu penciptaan busana. Sumber ide dapat diambil dari berbagai hal baik dan aspek kehidupan, maupun terinspirasi oleh peristiwa-peristiwa penting yang tengah terjadi seperti benda mati dan benda hidup. Sedangkan busana fantasi yang telah dibuat dapat diperkenalkan kepada masyarakat melalui sebuah pagelaran busana.

Salah satu contohnya adalah penciptaan busana fantasi dengan sumber ide yaitu Dramatari Calonarang. Dramatari Calonarang merupakan suatu seni tari yang berasal dari Pulau Bali. Menurut Deliana Harahap (2007:30) kesenian Dramatari Calonarang merupakan jenis tari yang dikatagoriakan kedalam tarian yang sakral atau tari Wali (religious dance). Bandem (2000:81) menyatakan Dramatari Calonarang merupakan salah satu kesenian Bali yang menunjukan sistem nilai budaya masyarakat. Dramatari ini sangat popular bagi masyarakat Bali sehingga dikenal oleh berbagai kalangan dari anak-anak, orang dewasa, hingga sampai orang tua. Calonarang merupakan cerita semisejarah yang mengisahkan kejadian pada zaman kerajaan Airlangga di Jawa Timur. Untuk melestarikan kisah Calonarang, maka diadaptasilah kedalam seni pertunjukan. Di Bali kisah Calonarang diadaptasi ke dalam Dramatari, dimana di dalam pertunjukan itu berisi tarian, nyanyian dan musik atau gamelan. Selain dari segicerita yang menarik, pada tarian 
ini juga seringkali menampilkan adeganadegan yang sangat menegangkan yang mengandung unsur magis yang membuat tarian ini semakin diminati.

Berdasarkan hasil survey dari team survey ASTI (2011) dalam Dramatari Calonarang memadukan 3 unsur penting yaitu Babarongan yang diwakili oleh Barong Ket, Rangda dan Celuluk, Unsur Pagambuhan diwakili oleh Condong, Putri, Patih Manis (Panji) dan Patih Keras (Pandung) dan Palegongan diwakili oleh Sisiya-sisiya (murid-murid). Tokoh penting lainnya dari dramatari ini adalah Matah Gede. Berdasarkan wawancara yang dilakukan dengan salah satu penari Matah Gede yakni Wira Sukma (2019) menyatakan bahwa Matah Gede adalah pemeran utama atau beliau yang paling penting dalam Dramatari pencalonarang. Hal ini dikarenakan dalam pemetasan Matah Gede selalu ada, dari dimulainya pementasan hingga berakhirnya pementasan.

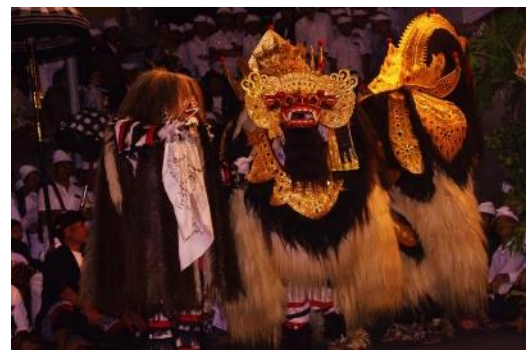

Gamabar1. 1: Barong dan Rangda Sumber:https://desabeloksidan.badungkab. go.id. html

Menurut Suartaya (2011) Keangkeran Matah Gede juga dibangun oleh dominasi tata ucapannya dalam bahasa Kawi, bahasa Jawa Kuno. Dalam kisah legenda Matah Gede juga memiliki sebutan lain yakni Walu Nate Ing Dirah. Jika dijabarkan Walu Nate Ing Dirah memiliki arti yaitu, Walu atau dalam Bahasa Bali desebut Balu yang berarti tanpa suami atau seorang janda, Nata yang artinya Raja atau Ratu, Ing yang artinya Di, dan Dirah adalah nama sebuah kerajaan. Maka Walu Nate Ing Dirah adalah seorang janda yang menjadi ratu di kerajaan Dirah. Namun di Bali lebih dikenal sebagai Matah Gede.
Dalam Dramatari Calonarang karakter Matah Gede hadir dengan jati diri perwatakan pemberang, tata busana, dan tata rias wajahnya. Pemberang adalah watak menonjol dari tokoh yang tak pernah lepas dari tongkatnya ini. Jika sedang naik pitam, sorot matanya yang menusuk tajam dilukiskan pantang dilawan jika tak ingin hangus terbakar. Memakai kain rembang dan kerudung putih serta tata polesan muka beraksen gurat-gurat keriput, penampilan tokoh ini menjadi lain dari yang lain, membangun struktur dramatik dan menghadirkan kekentalan tema utama teater ini yaitu sebagai drama of magic.

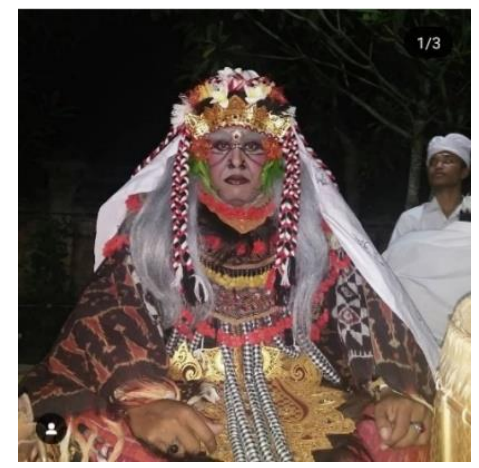

Gambar 1.2: Penari Matah Gede

Sumber: Dokumentasi Wira Sukma

Pertunjukan Dramatari Calonarang memberi inspirasi bagi penulis untuk menciptakan sebuah busana fantasi. Karena dalam Dramatari Calonarang terdapat karakter Matah Gede yang digambarkan sebagai sosok nenek tua yang seram dan memiliki aura magis. Sehingga penulis ingin merancang busana fantasi yang memberikan kesan yang berbeda yakni mistis, elegant dan anggun namun tidak menghilangkan ciri khas dari busana tari Matah Gede. Mengingat karakter penari Matah Gede juga menyimbolkan seorang ratu. Maka dalam pengembangan busana juga diinovasi sekreatif mungkin sehingga busana yang diciptakan memberikan kesan yang mewah dan agung.

$$
\text { Karena busana yang }
$$

dikembangkan adalah busana fantasi. Maka penulis menggunakan teknik pengembangan model planning, production, dan evaluation (PPE). Alasan 
pemilihan model ini dikarenakan model ini fokus dari perancangan dan penelitian pengembangan bersifat analisis dari awal sampai akhir, yang meliputi Perancangan, Produksi dan Evaluasi. pengembangan yang sederhana dan mudah dipelajari. Teknik pengembangan model PPE ini merupakan salah satu model pengembangan suatu produk baru, atau menyempurnakan produk yang telah ada dan dapat dipertanggungjawabkan hasilnya. Model PPE memberi peluang untuk melakukan evaluasi terhadap aktivitas pengembangan pada setiap tahap.

Hal ini berdampak positif yang ditimbulkan dengan adanya evaluasi pada setiap tahapan adalah meminimalisir tingkat kesalahan atau kekurangan produk pada tahap akhir model ini (Tegeh,2014: 41). Diharapkan dengan menggunakan model pengembangan ini, dapat dikembangkan sebuah produk berupa busana fantasi dengan sumber ide busana Dramatari Calonarang tanpa meninggalkan ciri khas dari busana penari Matah Gede

Berdasarkan latar belakang yang telah dipaparkan tersebut, perlu adanya penelitian untuk masalah tersebut dengan mengambil judul: pembuatan busana fantasi dengan sumber ide busana dramatari calonarang.

\section{METODE}

Dalam pengembangan busana fantasi ini, peneliti menggunakan metode penelitian dan pengembangan (Research and Development/R\&D).

Menurut Sugiyono (2019:31), "metode penelitian dan pengembangan dapat diartikan sebagai cara ilmiah untuk meneliti, merancang, memproduksi dan menilai produk yang telah dihasilkan". Pendapat lain diungkapkan oleh Richey dan Klein (Sugiyono 2019:37) mendefinisikan metode penelitian dan pengembangan sebagai berikut:

\footnotetext{
"the systematic study of design, development and evaluation processes with the aim of establishing an empirical basis for the creation of instructional and non-
}

instructional products and tools and new or enhanced models that govern their development".

Maksudnya, metode penelitian dan pengembangan merupakan studi sistematis mengenai proses perancangan, pengembangan dan penilaian dengan tujuan membangun dasar empiris untuk penciptaan suatu produk instruksional dan non instruksional, alat serta suatu model baru.

Dalam penelitian ini, peneliti mengadopsi langkah-langkah penelitian dan pengembangan model Planning, Production, Evaluation (PPE) menurut Richey dan Klein (Sugiyono 2019:37), yaitu dengan rincian sebagai berikut:

Tahap planning dalam penelitian pengembangan ini adalah perencanaan dalam pembuatan busana fantasi. Perencanan yang dilakukan yakni menganalisis warna-warna dan aksesoris yang terdapat pada busana penari Matah Gede, selain itu peneliti juga menggunakan aksesoris serta ornamen dalam pembuatan busana tari ini banyak terkandung unsur-unsur dari Bali seperti, hiasan ukiran-ukiran busana penari Matah Gede. Kemudian peneliti membuat suatu desain busana sesuai dengan sumber ide yang sudah ditetapkan

Peneliti membuat beberapa desain sketsa, kemudian dari desain tersebut dipilih dua desain yang sesuai untuk dijadikan sebagai busana fantasi. Setelah dua desain sketsa yang dipilih, kemudian membuat desain produksi dan analisis desain. Peneliti menggunakan teknik wawancara untuk menggali informasi dan studi dokumentasi tentang Dramatari Calonarang.

Tahap kedua pada model PPE yaitu production atau produksi. Produksi dalam penelitian ini menghasilkan dua produk busana fantasi dengan mengambil sumber ide dramatari calonarang. Beberapa ide diambil dari warna busana dan aksesoris penari Matah Gede. Selanjutnya dimulai dengan pengumpulan bahan, pengelolaan bahan, dan terakhir adalah produksi. Bahan-bahan yang dikumpulkan berupa kain untuk bahan utama, kain untuk bahan furing/linning, 
benang, dan alat-alat jahit. Setelah alat dan bahan terkumpul, dilakukan pengelolaan bahan oleh peneliti, yaitu dengan membuat suatu prodak busana fantasi yang sesuai dengan sumber ide dan teknik jahit yang digunakan dalam membuat busana.

Evaluasi merupakan kegiatan menilai produk yang dilakukan oleh ahli (expert judgment), Kegiatan evaluasi ini dilakukan guna mengetahui kekurangan atau kelemahan produk serta masukan ahli sehingga produk dapat memiliki kelayakan dan kualitas yang lebih baik untuk digunakan.

Dalam penelitian instrumen ini pengumpulan data yang digunakan berupa kuisioner. Kuisioner atau angket merupakan teknik pengumpulan data yang dilakukan dengan memberi seperangkat pertanyaan tertulis yang diberikan kepada responden untuk dijawab (Sugiyono 2009:199). Instrumen kuisioner pada penelitian pengembangan ini digunakan untuk memperoleh data dari ahli busana sebagai bahan evaluasi produk yang dikembangkan. Sebelum instrument kuisioner ini dapat dipergunakan, instrument ini dianalisis validitas isi oleh 2 judges ahli isi, yang dihitung dengan rumus Gregory, sehingga validitas instrumen diperolh sebesar 100\% dengan kriteria validitas sangat tinggi sehingga dapat digunakan untuk uji produk.

Dalam penelitian ini menggunakan teknik analisis deskriptif kuantitatif dan deskriptif kualitatif. Teknik analisis deskriptif kuantitatif digunakan untuk mengolah data yang diperoleh melalui angket uji produk dalam bentuk deskriptif presentase. Rumus yang digunakan untuk menghitung presentase dari masingmasing subyek adalah sebagai berikut:

$$
N=\frac{\text { skor perolehan }}{\text { skor maksimal }} \times 100 \%
$$

Selanjutnya, untuk menghitung presentase keseluruhan subjek digunakan rumus sebagai berikut:

Tabel 3.9

Konversi Tingkat Pencapaian

\begin{tabular}{|c|c|}
\hline $\begin{array}{c}\text { Tingkat } \\
\text { Pencapaian }\end{array}$ & Kualifikasi \\
\hline $90 \%-100 \%$ & Sangat Sesuai \\
\hline $75 \%-89 \%$ & Baik \\
\hline $65 \%-74 \%$ & Cukup \\
\hline $55 \%-64 \%$ & Kurang \\
\hline $0-54 \%$ & Sangat kurang \\
\hline
\end{tabular}

(Sumber: Tegeh, dkk, 2014)

Data dalam penelititian kualitatif bersifat deskritif bukan angka. Data dapat berupa gejala-gejala, kejadian dan peristiwa kemudian dianalisis dalam bentuk kategori-kategori. Analisis deskritif kualitatif yaitu suatu cara analisis/pengolahan data dengan jalan menyusun secara sistematis dalam bentuk kalimat/ kata-kata, kategorikategori mengenai suatu objek (benda, gejala, variabel tertentu), sehingga akhirnya diperoleh simpulan umum". Teknik analisis deskriptif kualitatif ini digunakan untuk mengolah data hasil uji produk ahli busana. Teknik analisis data ini dilakukan dengan mengelompokkan informasi-informasi dari data kualitatif yang berupa masukan, tanggapan, kritik dan saran perbaikan yang terdapat pada angket.

\section{HASIL DAN PEMBAHASAN}

Untuk memperoleh hasil Pengembangan dari busana fantasi dengan sumber ide Dramatari Calonarang dilakukan berdasarkan langkah-langkah dalam model pengembangan PPE yaitu Planning, Production Dan Evalution.

Pada tahap pertama, peneliti melakukan analisis kebutuhan serta membuat rancangan produk yang berupa desain produk. Produk yang penulis buat adalah pengembangan busana fantasi dengan sumber ide Dramatari Calonarang. Sebelum memulai pada tahap mendesain penulis menganalisis busana, warna-warna dan aksesoris yang terdapat pada busana penari Matah Gede, selain itu peneliti juga menggunakan aksesoris serta ornamen dalam pembuatan busana tari ini banyak terkandung unsur-unsur dari Bali seperti, hiasan ukiran-ukiran busana penari Matah Gede. Dari sumber ide tersebut dikembangkan unsur- unsur, prinsip- 
prinsip dan karakteristik dari busana penari Matah Gede yang digunakan untuk mengembangkan busana fantasi dalam penelitian ini. Desain busana fantasi yang terpilih, dibuat berdasarakan karakteritik busana fantasi dan ciri khas dari busana penari Matah Gede. Busana fantasi yang penulis kembangkan menggunakan akasesori yang sama antara desain satu dan dua. Pemilihan warna, bentuk serta motif juga serasi antara desain satu dan dua.
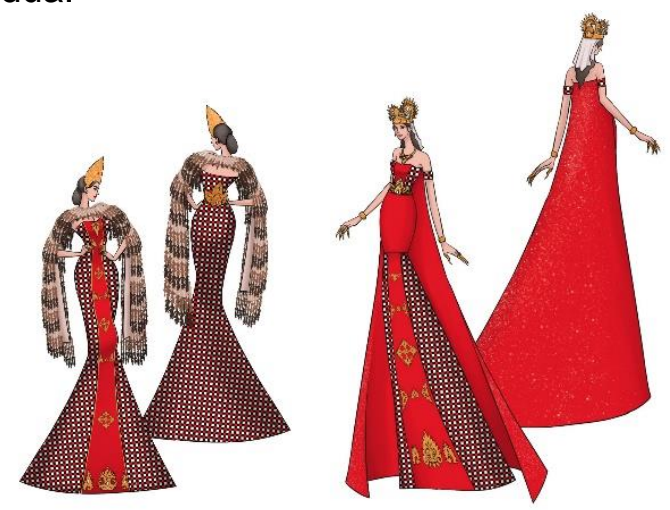

Gambar: Desain Busana Model 1\&2 Sumber: Dokumentasi Pribadi

akan Setelah menentukan desain yang dilanjutkan ketahap produksi. Pada tahap produksi dilakukan proses pengembangan produk melalui langkah-langkah pengembangan. Pada tahap pengembangan busana fantasi menggunakan bahan dasar kain katun bermotif dan kain bludru kemudian dilengkapi dengan ukiran-ukiran sebagai hiasan dan aksesoris. Adapun tiga tahapan dalam proses produksi ini yaitu, tahap persiapan, tahap menjahit dan finishing.

\section{a. Tahap Persiapan}

Pada tahap ini peneliti menyiapkan gambar kerja, kemudian dilanjutkan dengan mengambil ukuran yang diperlukan untuk membuat busana fantasi. Selanjutnya peneliti membuat pola yang akan digunakan untuk membuat busana fantasi. Setelah pola selesai kemudian akan dilanjutkan dengan membuat rancangan bahan dan harga. Tujuan dari pembuatan rancangan bahan dan harga ini, agar peneliti mengetahui berapa bahan yang diperlukan dan berapa jumlah harga dari bahan yang akan digunakan untuk pembuatan busana fantasi.

\section{b. Tahap Pelaksanaan}

$\begin{array}{ccc}\text { Setelah tahap persiapan } & \text { selesai, } \\ \text { kemudian } & \text { dilanjutkan } & \text { dengan }\end{array}$ pelaksanaan. Pada tahap pelaksanaan meliputi meletakkan pola diatas bahan yang disesuaikan dengan arah serat dan motif kain, kemudian dilanjutkan dengan memotong kain/bahan sesuai dengan pola, setelah itu dilanjutkan dengan proses penjelujuran dan penyambungan bagian-bagian dari busana pesta. Setelah proses penjelujuran selesai, dilanjutkan dengan evaluasi I. Pada proses ini, busana dipakai oleh seorang model dan dicek apakah busana tersebut sudah pas dan sesuai dengan bentuk desain busana yang akan dikembangkan. Kemudian dilanjutkan dengan proses menjahit secara permanen bagian-bagin dari busana. Setelah selesai proses menjahit, selanjutnya dilakukan evaluasi II, tujuan dari evaluasi ini adalah untuk mengecek kembali hasil jahitan setelah dilakukan proses menjahit dan juga melakukan proses finishing pada busana fantasi.

Tahap ketiga (Evaluation) Pada tahapan ini peneliti melakukan pengecekan secara keseluruhan terhadap hasil pengembangan busana fantasi sebelum dilanjutkan pada tahap uji prodak dan tahap perbaikan. Tujuan dari evaluasi ini adalah untuk mengetahui tingkat keberhasilan dari persiapan dan pelaksanaan dalam pembuatan busana fantasi. Evaluasi ini meliptuti keseluruhan bagian-bagian dari busana fantasi sampai dengan aksesoris dan milineris.

Uji prodak dilakukan oleh dua orang ahli busana yaitu lbu Putu Ria Yunita selaku Owner Ria Boutique dan Ibu Luh Nusari, S.Pd., selaku staf pengajar di SMK N 2 Singaraja.

Tabel 4.4

Hasil Validitas Uji Produk 


\begin{tabular}{|l|c|}
\hline Penilai & Hasil \% \\
\hline Ahli I & $100 \%$ \\
\hline Ahli II & $97 \%$ \\
\hline Total Nilai & $98,5 \%$ \\
\hline
\end{tabular}

Berdasarkan hasil uji produk pengembangan busana fantasi dengan sumber ide Dramatari Calonarang memiliki kualifikasi sangat baik dengan tingkat pencapaian $98,5 \%$. Kemudian terakhir yang dilakukan adalah tahap evaluasi secara formatif. Tujuan dari evaluasi ini adalah memperbaiki busana fantasi yang telah dikembangkan. Evaluasi dilakukan untuk perbaikanperbaikan sesuai dengan penilaian dan masukan yang diberikan oleh ahli busana. Pada tahapan ini, peneliti melakukan evaluasi menurut hasil penilaian dari ahli busana dan memperbaiki busana fantasi sesuai dengan masukan dan saran yang diberikan oleh ahli busana.
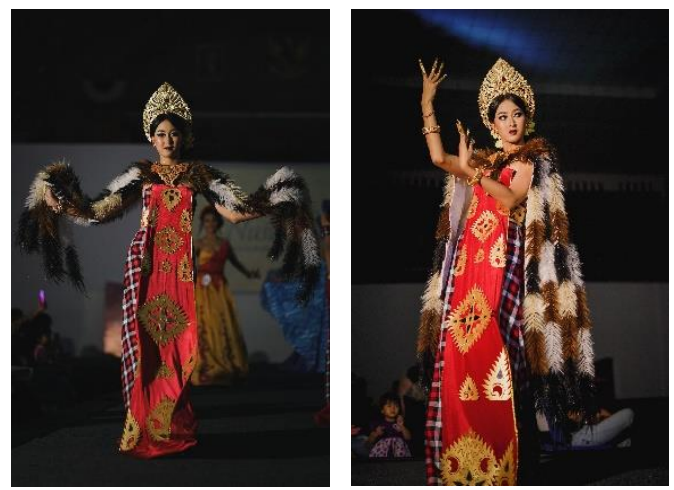

Gamabar 1 Hasil Pengembangan Busana Fantasi Model 1
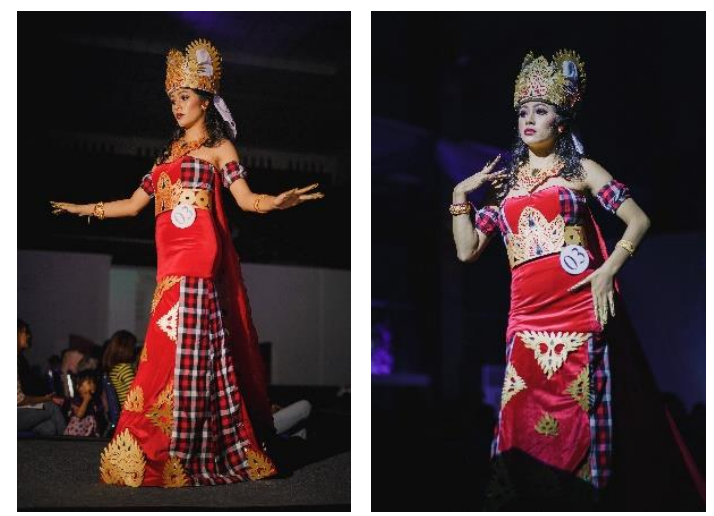

Gamabar 1 Hasil Pengembangan Busana Fantasi Model 2

\section{Hasil Penelitian}

Berdasarkan dengan proses pengembangan busana fantasi dengan sumber ide Dramatari. Mengambil hal-hal yang terkait dengan penari Matah Gede diambil sebagai sumber ide, seperti Bebet, Wastra, Jubah, Gelung, Tapih dan Aksesoris dari penari Matah Gede. Maka dapat terlihat hasil pengmbangan busana fantasi yang terdiri dari dua busana fantasi yaitu model busana I dan model busana II sebagai berikut:

Hasil pengembangan busana fantasi model I dengan sumber ide dari Dramatari Calonarang yang khusunya mengambil ide dari bentuk jubah, Tapih, bebet, wastra dan aksesorisnya. Busana yang di buat mengambil siluet $A$. Pada model I bentuk bebet dikembangkan menjadi model angkin yang menggunakan bukaan pada bagian belakang. Model wastra dikembangkan menjadi bentuk rok A-line yang dijahit menyatu pada bustier. Bagian Tapih dibuat melangsai hingga jatuh kelantai. Warna yang digunakan pada busana model I di fokuskana menggunakan warna Tri datu dengan motif kain kotak-kotak.

Pada bagian jubah diruabah menjadi bentuk lengan cape yang di modifikasi mengikuti bentuk tubuh model. Untuk hiasan pada jubah menggunakan hiasan bulu-bulu sintetis. Aksesoriss yang digunakan adalah hasil pengembangan bentuk dasar dari ampok-ampok dan badong. Warna aksesoris menggunakan 
warna dasar emas sesuai dengan aksesoris penari Matah Gede dan dihiasi denngan manik-manik dan kaca. Busana ini juga dilengkapi dnegan aksesoris gelang, kuku-kukuan, anting-anting dan sirkam yang menyerupai motif api-apian.

Hasil pengembangan busana fantasi model II dengan sumber ide dari baju, selendang, wastra, bebet dan aksesoris penari Matah Gede. Mengubah bentuk bebet menjadi bustier dengan bukaan samping dan dihiasain manikmanik pada atas bustier dan pada bagian belakang mengubah selendang menjadi model sayap yang menyatu pada bustier. Pada bagian wastra diubah menjadi bentuk rok span dan di kombinasi melebar pada bagian bawah. Serta mengubah model lengan menjadi model slop tidak menyatu dengan bustier.

Warna yang ditonjolkan pada model II adalah merah dan dikombinasikan dengan motif kotakkotak. Untuk hiasan pada busana menggunakan ukir-ukiran api yang di hias dengan warma emas dan kaca. Terdapat pengembangan pada model gelung yang dibuat lebih sederhana nanum tidak menghilangka ciri khasnya. Busana ini juga dilengkapi dnegan aksesoris gelang, kuku-kukuan, anting-anting dan sirkam yang menyerupai motif api-apian.

\section{PEMBAHASAN}

Dalam pengembangan busana fantasi dengan sumber ide Dramatari Calonarang ini menggunakan model pengembangan PPE. Model PPE menggunakan 3 tahap pengembangan yaitu, perencanaan, produksi dan evaluasi. Pada tahap perencanaan peneliti melakukan pengumpulan data untuk memecahkan masalah yang dihadapi peneliti tentang sumber ide dalam merancang/mendesain suatu produk busana fantasi. Sumber ide yang diambil pada Dramatari Calonarang merupakan busana dari penari Matah Gede. Adapun sumber ide yang diambil seperti bentuk busana, warna busana, aksesoris busana, yang merupakan satu kesatuan yang tidak terpisahkan antara satu dengan yang lainnya dalam busana tari. Hal ini diperkuat oleh penelitian Made Astini Siluh (2001) menyatakan bentuk, warna dan aksesoris busana dapat memberikan kesan khusus pada penonton dalam membedakan keras lembutnya masing-masing peran serta membedakan peran putra dan putri. Selain mengumpulkan data tentang sumber ide, peneliti juga mengumpulkan data tentang teori desain, busana fantasi, dan pola. Teori-teori ini didapatkan dari buku dan sumber lainnya.

Tahap pengembangan dalam penelitiam ini adalah pembuatan busana fantasi. Busana yang dikembangkan dengan menggunakan satu sumber ide yaitu Dramatari Calonarang. Hasil ini diperkuat oleh penelitian Zizka Meitria (2017) menyatakan busana fantasi yang diharapkan dapat mewujudkan daya cipta, gagasan atau konsep ke dalam suatu busana, sama seperti The Light of Aceh yang berusaha menggambarkan Aceh dalam satu kalimat. Sehingga dari pernyataan tersebut peneliti menggunakan sumber ide untuk menghasilkan sebuah bentuk baru dalam busana. Dalam pengembangan ini bentuk busana dibuat menjadi press body atau di kembangkan kedalam siluet I dan A agar lebih simpel dan praktis. Kemudian mengubah bentuk bebet menjadi model bustier dan mengubah bentuk wastra menjadi rok A-line dan rok span yang dikembangkan pada bagian bawahnya. Pada model jubah dirubah menjadi bentuk model lengan cape dan selendang dirubah menjadi sayap/ekor bagian belakang. Untuk warna mengfokuskan pada warna tri datu dan merah. Bahan yang digunakan untuk membuat busana adalah katun motif kotak-kotak dengan warna merah, putih dan hitam, kain bludru warna merah, kain satin, tile gliter, kain organza dan furing hero untuk bagian furing. Sedangkan untuk menghias penulis menggunakan permata, kaca, dan ukiran api-apian. Bahan pelengkap untuk pembuatan busana seperti benang, bisban, retsleting dan lain-lainnya.

Selanjutnya untuk mengetahui kualifikasi produk busana fantasi maka peneliti melakukan uji produk menggunakan instumen penilaian, uji 
produk dilakukan oleh dua orang ahli, ahli pertama berasal dari seorang guru jurusan tata busana SMKN 2 Singaraja dan ahli kedua seorang praktisi industri busana yang bertempat di Singaraja. Hasil uji produk pengembangan busana fantasi yang terlihat pada tabel 4.2 memperlihatkan hasil uji produk ahli I dengan presentase $100 \%$ dan ahli II dengan presentase $97 \%$ dengan total kedua ahli yaitu $98,5 \%$ dengan perhitungan tersebut, maka kualifikasi produk pengembangan busana fantasi dengan sumber ide Dramatari Calonarang di katagorikan sangat baik.

Dari hasil penelitian pengembangan busana dengan sumber ide Dramatari Calonarang, terdapat dua jenis busana fantasi diamana setiap model busana ada perbedaan. Meskipun sumber ide yang diambil sama yaitu tentang Dramatari Calonarang akan tetapi mengjhasilkan busana yang berbeda antara model I dan model II. Dilihat dari model I menggunakan jubah dan model roak Aline serta menggunakan lidah atau selibah pada bagian depannya dan menggunakan furing buka. Sedangkan model busana II menggunakan model 2 piece pada bagian bustier menggunakan bukaan di samping. Bagian belakang bustier menggunakan hiasan sayap. Pada bagian rok menggunakan model rok span yang kombinasi dan menggunakan hiasan lengan, serta menggunakan furing lepas.

\section{SIMPULAN}

Pertunjukan Dramatari Calonarang memberi inspirasi bagi penulis untuk menciptakan sebuah busana fantasi. Karena Dramatari Calonarang terdapat karakter Matah Gede yang digambarkan sebagai sosok nenek tua yang seram dan memiliki aura magis.

Pengembangan busana fantasi dengan sumbr ide Dramatari Calonarang menggunakan langkah-langkah pengembangan dengan model PPE. Dimana langkah-langkah tersebut terdiri dari tiga langkah yaitu: Perencanaan (Planning), Produksi (Production), dan Evaluasi (Evaluation). Berdasarkan hasil pengembangan busana yang diciptakan, maka didapatkan hasil dari pengembangan busana fantasi dengan sumber ide Dramatari Calonarang memiliki kualifikasi sangat baik dengan presentase perolehan $98,5 \%$ berdasarkan hasil penilaian ahli busana. Dari hasil penilaian tersebut menunjukan bahwa produk yang dikembangkan masih belum sempurna dan perlu adanya perbaikanperbaikan dari hasil pengembangan busana fantasi dengan sumber ide Dramatari Calonarang.

\section{SARAN}

Adapun saran yang dapat disampaikan Berdasarkan hasil yang diperoleh dari penelitian ini bahwa pengembangan busana fantasi dengan sumber ide Dramatari Calonarang ini mendapatkan penilaian dengan kualifikasi sangat baik dari penilaian ahli busana. Sehingga bisa dijadikan sebagai acuan bagi pengembangan busana fantasi selanjutnya dengan mengambil sumber ide yang sama.

\section{DAFTAR RUJUKAN}

Al-Firdaus, Iqra'.2010. Inspirasi- inspirasi Menakjubkan Ragam Kreasi Busana. Yogyakarta: Diva Press.

Bandem, I Made. 2000. Etnologi Tari Bali. Yogyakarta: Kanisius.

Deliana Harahap, Frida. 2007. "Masyarakat dan Kesenian Bali dan Nusa Tenggara". Jurnal Etnomusikologi, Nomor 6, Tahun 3, September 2007. Universitas Sumatera Utara.

Kamus Besar Bahasa Indonesia. 2019. "Pengertian Fantasi". Tersedia pada https://Kamus Besar Bahasa Indonesia.kemdikbud.go.id/entri/FA NTASI (diakses pada tanggal 8 Maret 2019)

Kusalamani. 2017, 21 Maret. "Mengenal Aneka Dramtari di Indonesia". Tersedia pada https://www.tembi.net/2017/03/21/ 
Jurnal Bosaparis: Pendidikan Kesejahteraan Keluarga

Volume 10, Nomor 3, November 2019

mengenal-aneka-dramatari-diindonesia/ ( diakses pada tanggal 22 Febuari 2019).

Meitra, Ziska, Dkk. 2017. Pembuatan Busana Fantasi Dengan Sumber Ide the Light of Aceh. Volume 2 Nomor 4 November 2017 Hal: 78-83. Universitas Syiah Kuala.

Suartaya, Kadek. 2011, 16 Juni. "Janda Jantan Ni Calonarang, Mengerang Garang Menantang Penguasa" Tersedia pada https://www.isidps.ac.id/berita/janda-jantan-niCalonarang-mengerang-garangmenantang-penguasa/ ( diakses pada tanggal 22 Febuari 2019).

Siluh Made Astini. 2001. Makna Dalam Busana Dramatari Arja DI Bali. Volume 2, Nomor 2 Tahun 2001. Universitas Negeri Semarang.

Sugiyono. (2019). Metode Penelitian Kuantitatif, Kualitatif dan R\&B. Jakarta: Alfabeta.

Tegeh, I Made dkk. 2014.Model Penelitian Pengembangan. Singaraja: Graha Ilmu.

Team Survey ASTI. 2011. "Dramatari Calonarang". Tersedia pada http://www.babadbali.com/seni/dram a/dt-Calonarang.htm (diakses pada tanggal 23 Febuari 2019).

\section{Narasumber}

I Made Wira Sukma S.sos., 26 tahun. Desa Buruan, Kecamatan Blahbatuh. Diwawancarai tanggal 17 Maret 2019. 